Historic, archived document

Do not assume content reflects current scientific knowledge, policies, or practices. 

$=7640$

C 3 United States

Department

of Agriculture

Forest Service

Intermountain

Research Station

Research Paper

INT-409

September 1989

UAS

\section{Influence of Overstory} Removal and

Western Spruce Budworm Defoliation on Growth of Advance Conifer Regeneration in Montana

Clinton E. Carlson

Wyman C. Schmidt

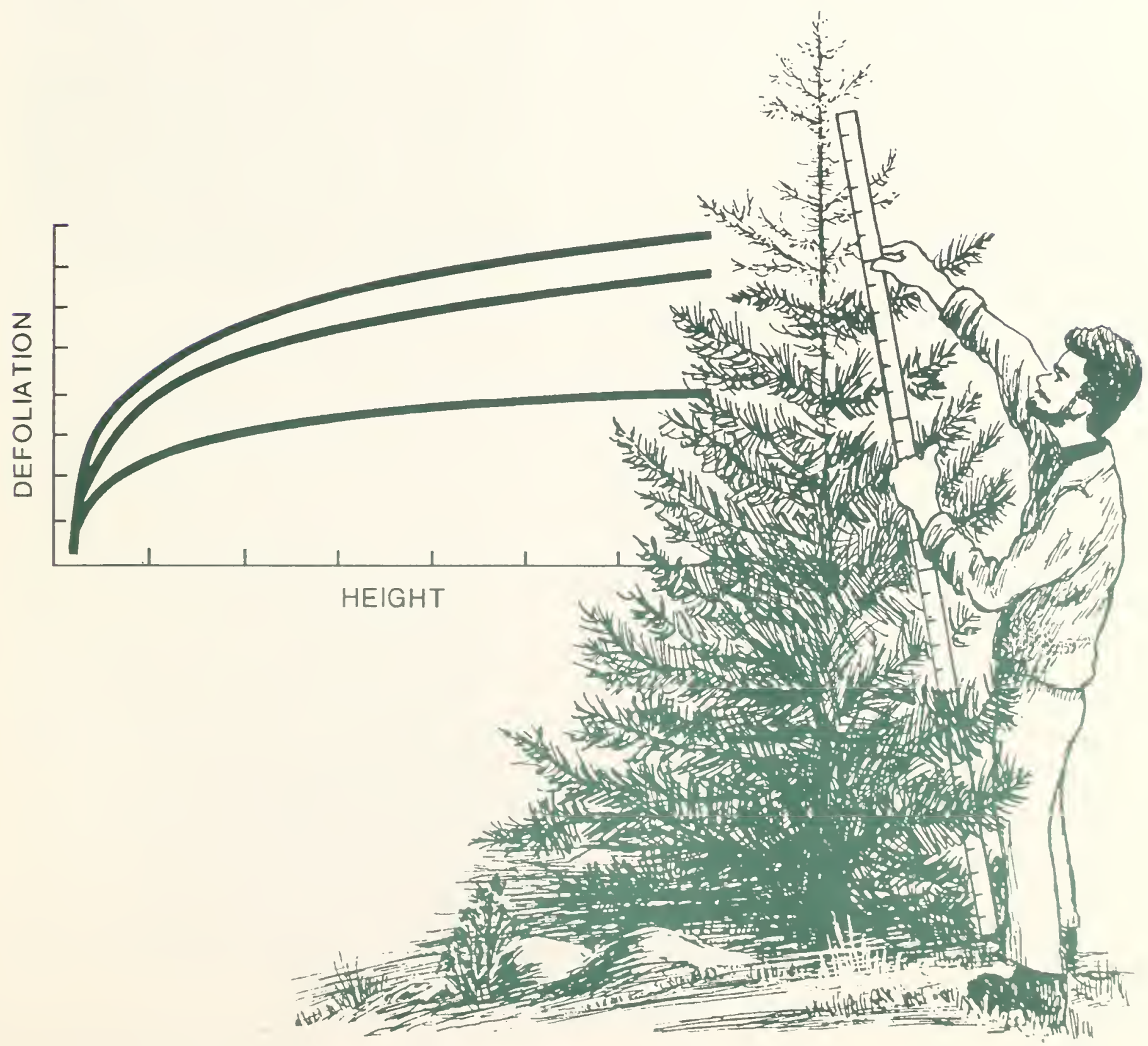




\section{THE AUTHORS}

CLINTON E. CARLSON is a research forester at the Intermountain Research Station, Forestry Sciences Laboratory, Missoula, MT. He has conducted extensive work on the effects of air pollution on forest ecosystems. He currently is researching interactions between western spruce budworm and forests in the Northern Rocky Mountains and hybridization between western and alpine larch. He holds B.S. and M.S. degrees in forestry and a Ph.D. in botany from the University of Montana.

WYMAN C. SCHMIDT is a research silviculturist and Project Leader of the Silviculture of Conifers in Montane and Subalpine Ecosystems of the Intermountain and Northern Rocky Mountain West research work unit at the Forestry Sciences Laboratory, Bozeman, MT. Dr. Schmidt's research has focused on the ecology, regeneration processes, stand development, and related cultural practices in coniferous forests of the Intermountain West. Much of his research has centered on the interrelationships of timber, water, and other resources as well as the interaction of cultural practices with insect pests such as western spruce budworm.

\section{RESEARCH SUMMARY}

The influence of four levels of overstory removal on height and diameter growth of advance regeneration was assessed in larch/Douglas-fir stands in subalpine fir habitat types of northwestern Montana. This study was part of a much larger effort focused on utilization of trees at Coram Experimental Forest. Twelve-year diameter growth of Douglas-fir and Engelmann spruce accelerated with increasing overstory removal, whereas subalpine fir diameter growth increased as the amount of basal area removed increased. Eleven-year height growth of Douglas-fir increased with increasing change in basal area; height growth of subalpine fir increased with both change in basal area and degree of overstory removal. Height growth of spruce increased only with increasing prerelease 10-year radial growth. For Douglas-fir and subalpine fir, height and diameter growth responded to some measure of reduced competition. Nevertheless, radial growth prior to treatment was the variable most indicative of both height and diameter growth of all species. Trees growing well before treatment also grew well following treatment. Mortality was lowest where either all or none of the overstory was removed and was greatest where about 50 percent of the overstory was removed. Western spruce budworm, present in damaging numbers during study establishment, declined soon after harvest and was not present during remeasurement. Defoliation at time of study establishment was greatest on taller trees of all species but significantly affected height growth only of Douglas-fir. Because of the mediocre growth response and the increased susceptibility of such stands to budworm, future volumes in stands composed of and managed for shade-tolerant species may be substantially below volumes expected from stands composed of seral species in these high-quality habitats. 


\title{
Influence of Overstory Removal and Western Spruce Budworm Defoliation on Growth of Advance Conifer Regeneration in Montana
}

\author{
Clinton E. Carlson \\ Wyman C. Schmidt
}

\section{INTRODUCTION}

Mature conifer forests in the Northern Rocky Moun. tains usually have an uneven-aged understory of shadetolerant conifers, primarily because frequency of surface fires has decreased dramatically since the early 1900 's (Arno 1980; Marsden 1983). Larch/Douglas-fir (Larix occidentalis Nutt/Pseudotsuga menziesii var.glauca [Beissn.] Franco) forests on subalpine fir (Abies lasiocarpa [Hook.] Nutt.) habitat types (h.t.'s) (Pfister and others 1977) are no exception, usually supporting an extensive understory of subalpine fir, Engelmann spruce (Picea engelmannii Parry), and Douglas-fir. These are productive habitat types. Pfister and others (1977) rank Abies lasiocarpa /Clintonia uniflora h.t.'s as moderate to highly productive compared to Douglas-fir h.t.'s. Even-aged silviculture often is recommended for these forests, wherein following harvest the advance regeneration is destroyed during site preparation and the stand is subsequently regenerated to seral conifers (Schmidt and others 1983). At times, however, foresters may elect to culture the advance regeneration instead of regenerating a new even-aged stand. Few data exist concerning the performance of advance regeneration after commercial harvest in larch/Douglas-fir forests in the Northern Rockies, and with the current interest in uneven-aged management (implying a significant component of advance shadetolerant species) it is of considerable interest to know something about its expected growth. Furthermore, western spruce budworm (Choristoneura occidentalis Freeman) is present over much of the Northern Rockies (Johnson and Denton 1975), so we also need to understand more about the effects of the insect in stands of advance regeneration.

Research in forest types other than the larch/Douglasfir in the Western United States indicates that advance regeneration will release after harvest of merchantable trees. In the spruce/fir type, height growth of Engelmann spruce and subalpine fir advance regeneration accelerated following harvest (McCaughey and Schmidt 1982). Regeneration in clearcuts responded better than in partial cuts, whereas understory trees in the controls did not release. Other studies documenting release of conifer advance regeneration in the Western United States

following overstory removal include: California red fir (Abies magnifica A. Murr.) (Oliver 1986); grand fir (Abies grandis [Dougl.] Forbes) (Ferguson and Adams 1980; Seidel 1980); California red fir, white fir (Abies concolor [Gord. \& Glend.] Lindl.), and Douglas-fir (Helms and Standiford 1985); subalpine fir, white spruce (Picea glauca [Moench] Voss), and black spruce (Picea mariana [Mill.] B.S.P.) (Johnstone 1978). Most of these studies compared growth prior to clearcutting to postharvest performance rather than investigating effects of overstory removal per se. The purpose of our study was to develop equations to predict postharvest height and diameter growth of advance subalpine fir, Engelmann spruce, and Douglas-fir regeneration in productive subalpine fir habitats and to assess impact of western spruce budworm on the regeneration.

\section{METHODS}

\section{Field Study Design}

The study was conducted at the Intermountain Research Station's Coram Experimental Forest in northwestern Montana from 1973 to 1984. This study was part of a much larger research and development program dealing with logging systems, utilization, and biological responses (Barger 1980). Elevation in the study area ranges from 4,400 feet mean sea level (m.s.l.) in block 1 to 5,000 feet m.s.l. in block 2. Predominant aspect is east, slopes generally are steep-greater than 50 percent-and annual precipitation is 25 to 35 inches. Habitat type (Pfister and others 1977) over most of the area is Abies lasiocarpa /Clintonia uniflora. A western larch/Douglasfir cover type occupied the area prior to treatment. Stands were two-storied, with dominant and codominant trees averaging about 25 inches diameter breast height (d.b.h.) and 130 feet tall. Average diameter of the understory was about 3 to 4 inches d.b.h. and height about 25 to 35 feet.

Four treatments, randomly assigned within two blocks, were tested: (1) removal of all overstory and all understory trees larger than 7 inches d.b.h.; (2) removal of about 50 percent of the overstory and removal of understory trees larger than 7 inches d.b.h.; (3) removal of all 
overstory and understory trees larger than 7 inches d.b.h. in small blocks less than 2 acres in size; and (4) control, where no harvesting was done. Overstory was defined as the canopy stratum that included dominant and codominant trees, whereas understory included all other trees. Unit size for treatments 1 and 2 varied from 3 to 6 acres, and treatments 3 and 4 were about 1.5 acres. Volumes removed in blocks 1 and 2 , respectively, were 4,962 and $3,533 \mathrm{ft}^{3} /$ acre for treatment $1 ; 2,950$ and 2,570 for treatment 2; and 7,655 and 6,241 for treatment 3 (Benson and Gonsior 1981).

Ten $1 / 50$-acre circular plots were systematically established in each treatment, spaced about equally throughout the area. All trees on the plots were numbered with metal tags and measured in 1973 , prior to treatment. We remeasured the trees in summer 1985 using the 1984 terminal bud scar as the reference for current height. Thus, the time interval for height growth was 11 years. But because d.b.h. measurements necessarily included 1985 cambial growth, the interval for diameter growth was 12 years. We sampled only the first 10 trees encountered on the plot, beginning at north azimuth and proceeding clockwise, because preliminary data indicated that an adequate sample for assessing growth response could be obtained in this way. Furthermore, in 1985 we sampled only trees not killed or seriously damaged by the logging process because Benson and Gonsior (1981) had al ready reported on that aspect of the study.

Variables recorded for each tree were:

1. Species.

2. Degree of overstory removal. Coded 1 if partial removal; 2 , if total removal on treatment sites greater than 3 acres; 3 , if total removal on treatment sites smaller than 3 acres; and 4, for no overstory removal, the control.

3. Total height, to nearest 1 foot.

4. D.b.h., nearest 0.1 inch.

5. Length of live crown, nearest 1 foot.

6. Crown class (dominant, codominant, intermediate, suppressed, or open grown).

7. Mortality not caused by logging.

8. Ten-year radial growth prior to 1973 , inch.

9. Percent of foliage removed by western spruce budworm, by crown thirds, visual estimate.

For item 8 , increment cores were taken at breast height from plot trees 1 inch d.b.h. and larger to determine age and 10-year radial increment to the nearest 0.0004 inch for the period 1964-73. Smaller trees were a special problem because we felt that extracting a core would alter their growth. And disks could not be taken from the small permanent sample trees because that would have destroyed them. Therefore, we collected disks from small trees (surrogates) nearby, but not within the plots, so we could develop predictive models for prerelease 10-year radial growth of small trees on the permanent plots. Twenty trees each of Douglas-fir, Engelmann spruce, and subalpine fir within each of five height classes were selected without bias. Classes were 0 to $2.0,2.1$ to $3.0,3.1$ to 4.0 , and 4.1 to 5.0 feet. Total height and crown length were recorded for each tree. Disks were cut transversely just above the root collar of each tree, placed in plastic bags, and frozen at the end of each field day. Tenyear radial increment was measured in the laboratory to the nearest 0.0004 inch.

\section{DATA ANALYSIS}

We used multiple linear regression analyses to develop predictive models for 11-year height and 12-year diameter growth and to test statistical significance of independent variables. If needed, data were transformed to meet assumptions underlying regression analysis. All variables except degree of overstory removal were continuous; dummy variables were created for the categories of this variable. Variables were deemed significant at $P \leq 0.05$. Similarly, the influence of tree and plot variables on defoliation by budworm was tested using multiple linear regression procedures. Multiple linear regression was performed on the data from the small surrogate trees, using 10-year radial growth as the dependent variable and height and crown length as independent variables. Separate regressions were developed for each species. Missing values for small trees on the permanent plots were then computed using coefficients developed in the regressions. Mortality was analyzed using a linear modeling procedure for categorical data (Grizzle and others 1969). All data management and analyses were done with SAS procedures (SAS Institute 1985).

\section{RESULTS}

\section{Height Growth}

Degree of overstory removal had no effect on post-release height growth of advance Douglas-fir regeneration, but increasing change in basal area had a positive influence, reflecting the release from competition. Basic statistics for all variables are given in table 1 and regression models for estimating 10-year prerelease radial growth for small trees are presented in table 2. (Height and crown length were significant predictors $(P \leq 0.05)$ of prerelease radial growth for all three species.) Tree age was not used in any of the analyses because the data had been misplaced and could not be recovered. The natural log of postrelease 11-year height growth was directly related to 10 -year radial increment prior to treatment (table 3 ); height growth increased with larger radial growth (fig. 1). Defoliation by western spruce budworm tended to depress height growth of Douglas-fir. Figure 2 shows the combined effects of prerelease radial growth and defoliation on postrelease height growth, and figure 3 shows the influence of change in plot basal area. The height growth model for Douglas-fir was not very strong; the coefficient of multiple determination (CD) was only 0.20.

Postrelease height growth of Engelmann spruce increased with increasing prerelease radial growth $(C D=$ 0.15 ), but none of the other variables tested exerted a significant influence (table 3 , fig. 1 ). 
Table 1-Means, standard deviations, and sample sizes of variables used in the regression analyses of 11-year height growth, 12-year diameter growth, and budworm defoliation of Douglas-fir, subalpine fir, and Engelmann spruce

\begin{tabular}{|c|c|c|c|}
\hline Varlable & $\mathbf{n}$ & Mean & $\begin{array}{l}\text { Standard } \\
\text { deviation }\end{array}$ \\
\hline \multicolumn{4}{|c|}{ Douglas-fir } \\
\hline Natural log height growth & 160 & 0.275 & 1.533 \\
\hline Natural log d.b.h. growth & 160 & -.657 & .914 \\
\hline Overstory removal 1 & 160 & .206 & .405 \\
\hline Overstory removal 2 & 160 & .188 & .392 \\
\hline Overstory removal 3 & 160 & .075 & .264 \\
\hline 1973 height, feet & 160 & 15.256 & 13.111 \\
\hline 1973 d.b.h., inch & 160 & 2.052 & 1.992 \\
\hline Crown ratio & 160 & .497 & .251 \\
\hline Plot basal area, $\mathrm{ft}^{2}$ & 160 & 1.702 & 1.653 \\
\hline Basal area change, $\hbar^{2}$ & 160 & .950 & 1.500 \\
\hline 10-year radial growth, inch & 147 & .144 & .098 \\
\hline Percent defoliation & 140 & 31.536 & 27.423 \\
\hline Coefficient variable height & 147 & 103.565 & 55.139 \\
\hline \multicolumn{4}{|c|}{ Engelmann Spruce } \\
\hline Natural log height growth & 84 & 0.675 & 1.623 \\
\hline Natural log d.b.h. growth & 84 & -.420 & .843 \\
\hline Overstory removal 1 & 84 & .321 & .470 \\
\hline Overstory removal 2 & 84 & .060 & .238 \\
\hline Overstory removal 3 & 84 & .143 & .352 \\
\hline 1973 height, feet & 84 & 15.643 & 14.097 \\
\hline 1973 d.b.h., inch & 84 & 2.256 & 2.117 \\
\hline Crown ratio & 84 & .553 & .226 \\
\hline Plot basal area, $\mathrm{ft}^{2}$ & 84 & 2.105 & 2.088 \\
\hline Basal area change, $\mathrm{ft}^{2}$ & 84 & 1.399 & 2.166 \\
\hline 10-year radial growth, inch & 72 & .179 & .159 \\
\hline Percent defoliation & 69 & 51.638 & 28.369 \\
\hline Coefficient variable height & 72 & 95.083 & 34.259 \\
\hline \multicolumn{4}{|c|}{ Subalpine Flr } \\
\hline Natural log height growth & 229 & 0.240 & 1.553 \\
\hline Natural log d.b.h. growth & 229 & -.961 & 1.037 \\
\hline Overstory removal 1 & 229 & .114 & .318 \\
\hline Overstory removal 2 & 229 & .183 & .388 \\
\hline Overstory removal 3 & 229 & .183 & .388 \\
\hline 1973 height, feet & 229 & 7.039 & 10.928 \\
\hline 1973 d.b.h., inch & 229 & .833 & 1.600 \\
\hline Crown ratio & 229 & .701 & .287 \\
\hline Plot basal area, $\mathrm{ft}^{2}$ & 229 & 1.667 & 1.986 \\
\hline Basal area change, $\mathrm{t}^{2}$ & 229 & 1.099 & 1.701 \\
\hline 10-year radial growth, inch & 229 & .122 & .116 \\
\hline Percent defoliation & 217 & 35.083 & 28.631 \\
\hline Coefficient variable height & 221 & 144.624 & 60.979 \\
\hline
\end{tabular}


Table 2-Regression models for predicting prerelease 10-year radial growth (inch) of trees less than 1.0 inch d.b.h.

\begin{tabular}{|c|c|c|c|c|}
\hline Varlable & Coefficient & & $T$ & Probability \\
\hline \multicolumn{5}{|c|}{ Douglas-fir } \\
\hline Height & -0.004 & & -1.02 & 0.309 \\
\hline Crown length & .051 & & 5.91 & 0 \\
\hline Intercept & .039 & & 2.95 & .004 \\
\hline R-square & & & & \\
\hline Error mean square & & .01 & & \\
\hline \multicolumn{5}{|l|}{ F for model (Probability) } \\
\hline \multicolumn{5}{|c|}{ Engelmann Spruce } \\
\hline Height & -0.038 & & -4.59 & 0 \\
\hline Crown length & .096 & & 8.96 & 0 \\
\hline Intercept & .043 & & 2.42 & .018 \\
\hline R-square & & 0.62 & & \\
\hline Error mean square & & .01 & & \\
\hline F for model (Probability) & & 76.35 & & \\
\hline \multicolumn{5}{|c|}{ Subalpine Fir } \\
\hline Height & -0.016 & & -1.28 & 0.203 \\
\hline Crown length & .079 & & 5.30 & \\
\hline Intercept & -.001 & & -.06 & .949 \\
\hline R-square & & 0.69 & & \\
\hline Error mean square & & .01 & & \\
\hline F for model (Probability) & & 103.41 & & \\
\hline
\end{tabular}

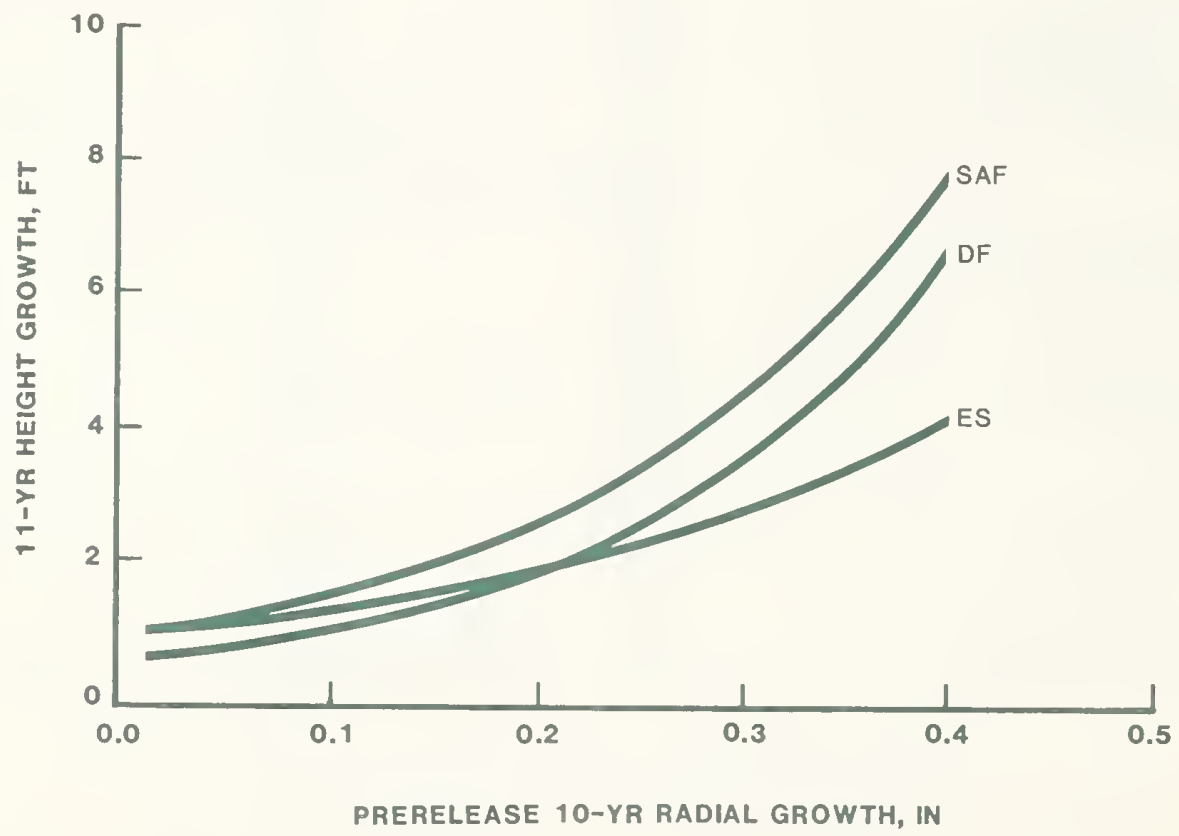

Figure 1-Relationship of 11-year postrelea se height growth of subalpine fir, Douglas-fir, and Engelmann spruce to 10-year prerelease radial growth. 


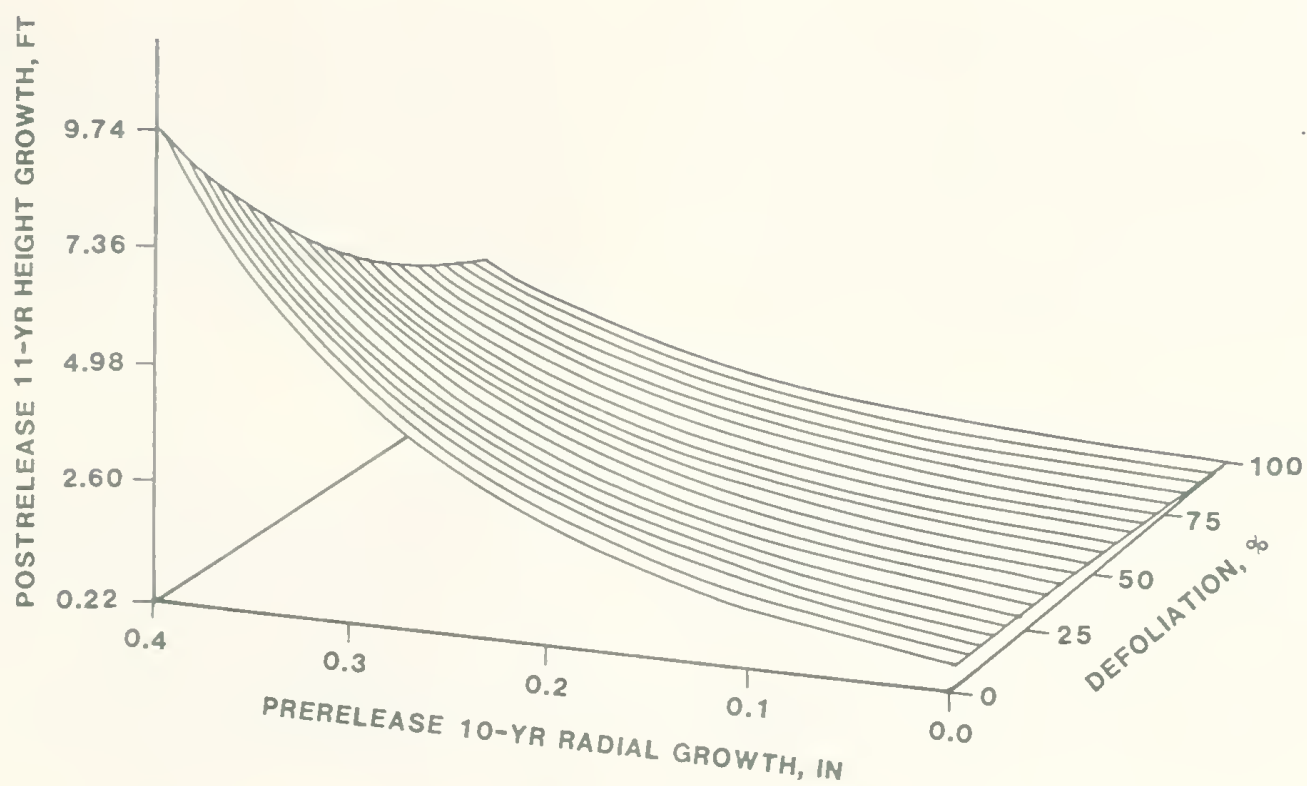

Figure 2-Relationship of 11-year postrelease height growth of Douglas-fir to 10-year prerelease radial growth and western spruce budworm defoliation.

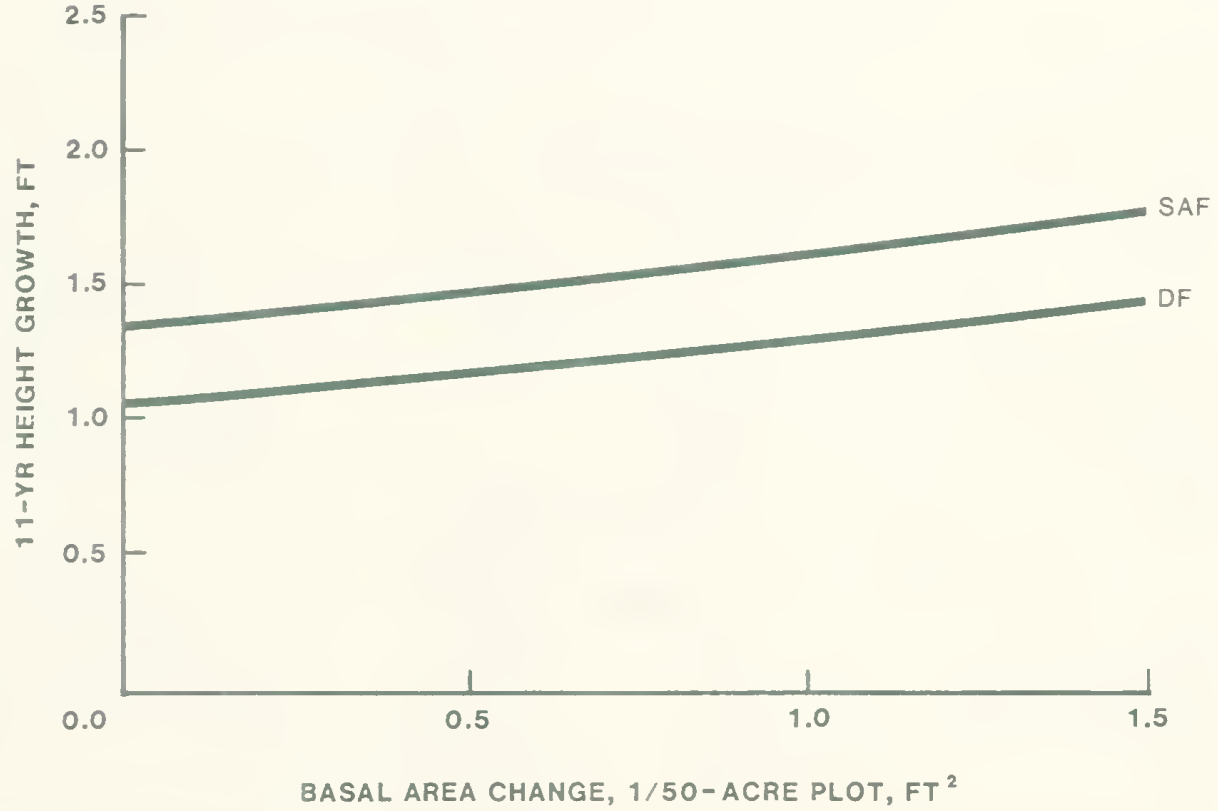

Figure 3-Effect of change in plot basal area on 11-year postrelease height growth of Douglas-fir and subalpine fir. 
Height growth of subalpine fir was influenced by degree of overstory removal and several other variables. Trees grew best when all the overstory was removed but grew least in the control and partial removal. Increasing basal area change and prerelease diameter growth also resulted in better height growth (figs. 1,3 ). We did not detect a significant influence of budworm on subalpine fir height growth (table 3 ). This was the strongest height growth model; even so, the $\mathrm{CD}$ was only 0.27 .

\section{Diameter Growth}

Models for predicting 12-year postrelease diameter growth were much stronger than for height growth and showed the release from competition. Ten-year radial growth preceding treatment (fig. 4), d.b.h. at time of treatment, and degree of overstory removal were significant in the model developed for Douglas-fir (table 4) and the CD was 0.53 , far larger than for the height growth model of this species. Larger, faster-growing trees where all the overstory was removed grew best. Budworm had no detectable influence.

Posttreatment diameter growth of Engelmann spruce increased with increasing prerelease radial growth and degree of overstory removal (table 4, fig. 4). We did not detect any influence of basal area change, budworm, or other variables tested. The CD for spruce was 0.45 , also much larger than for the height growth model.
Diameter growth of subalpine fir responded positively to increasing basal area change and 10-year prerelease radial growth (table 4 , fig. 4). The coefficient of multiple determination was 0.50 . Oddly enough, trees with smaller crown ratios responded better than those with larger crown ratios. Degree of overstory removal had no influence on diameter growth. Again, budworm did not significantly influence postrelease diameter growth of this species.

\section{Mortality}

Chi-square tests indicated that cutting type and species significantly influenced postharvest mortality (table 5). The interaction was nonsignificant. Percent mortality for all species combined, since the study began in 1973, was nearly the same-13 to 14 percent-among the complete overstory removal and control treatments (table 6). In the partial removal, however, mortality was substantially greater-about 25 percent. Among species, mortality was highest for Douglas-fir at 22 percent but about 13 percent for the subalpine fir and spruce. Average mortality over all species and treatments was about 16 percent for the 12-year period, or 1.3 percent per year.

Table 3-Regression equations predicting natural log of 11-year post release height growth of Douglas-fir, Engelmann spruce, and subalpine fir

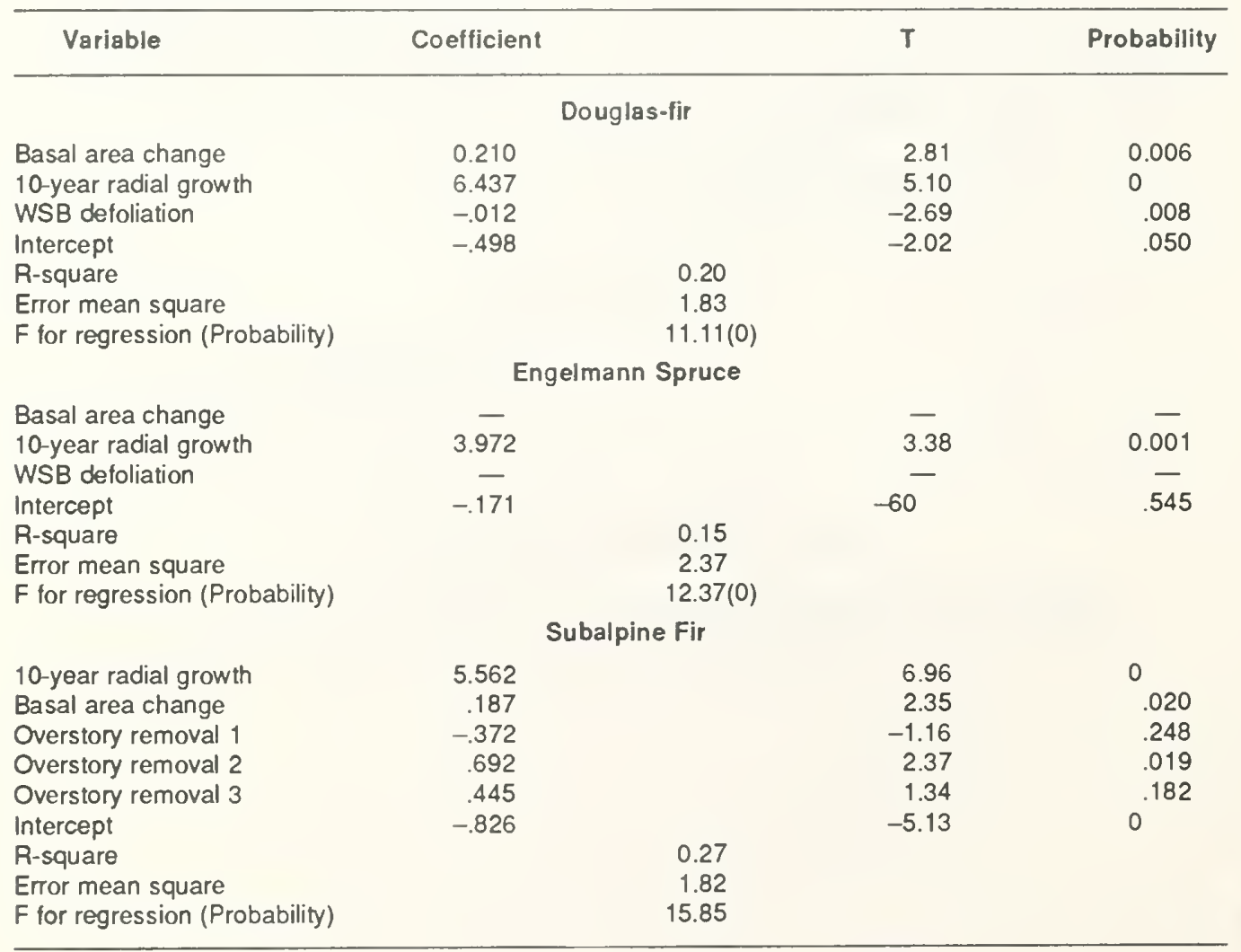




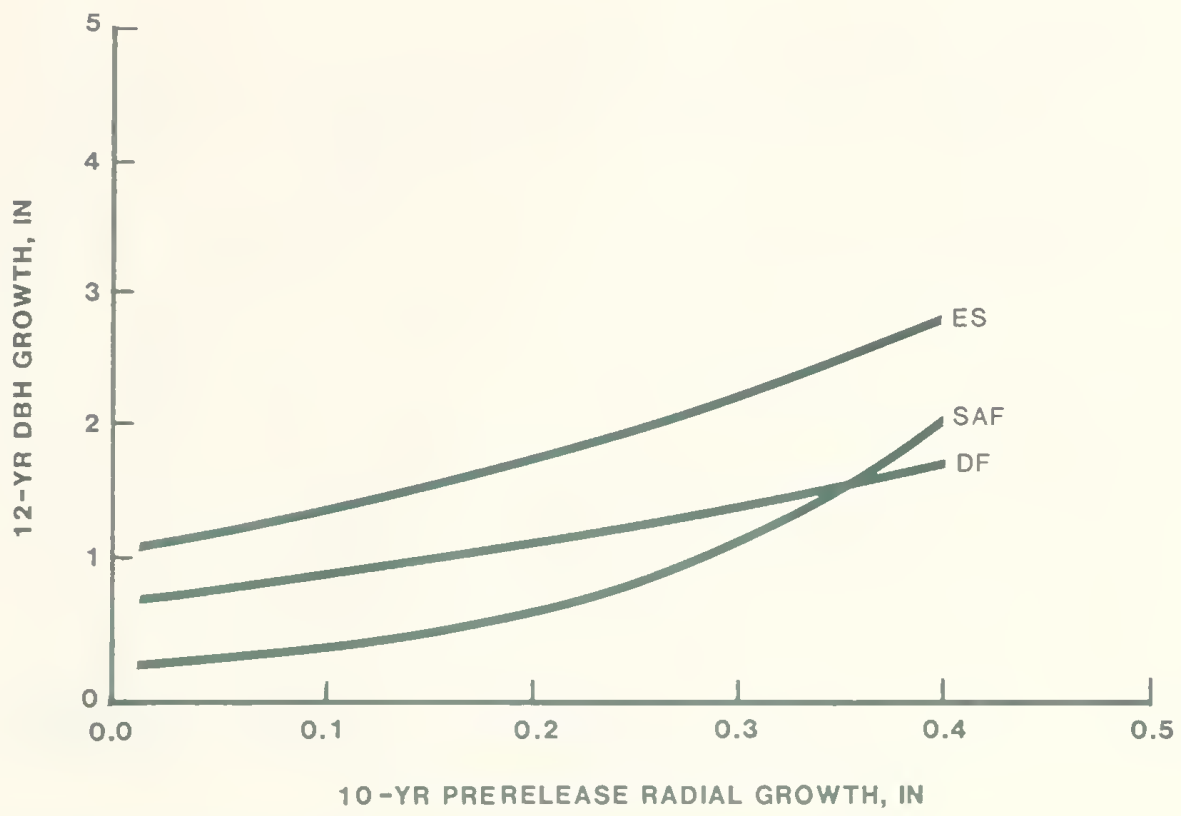

Figure 4-Relationship of 12-year postrelease diameter growth of Douglas-fir, subalpine fir, and Engelmann spruce to 10 -year prerelease radial growth.

Table 4-Regression equations predicting natural log of 12-year post release d.b.h. growth of Douglas-fir, Engelmann spruce, and subalpine fir

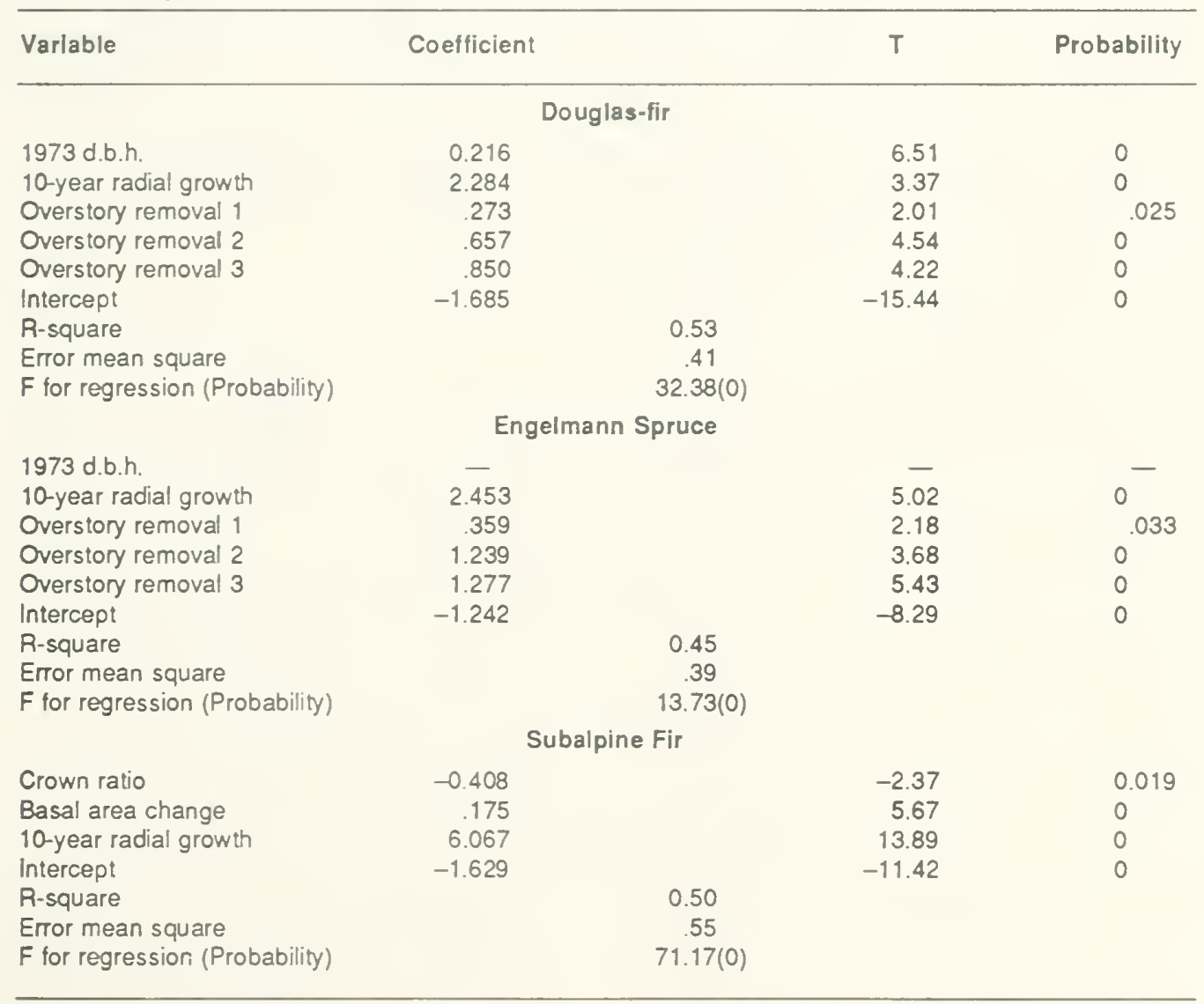


Table 5-Analysis of variance of mortality data

\begin{tabular}{lccc}
\hline Source of variation & Degrees of freedom & Chi-square & Probability \\
\hline Intercept & 1 & 133.00 & 0.0001 \\
Cutting type & 3 & 7.87 & .0487 \\
Species & 2 & 6.70 & .0351 \\
\hline
\end{tabular}

Table 6-Influence of overstory removal and species on mortality of advance regeneration

\begin{tabular}{|c|c|c|c|c|c|}
\hline \multirow[b]{2}{*}{ Species } & \multicolumn{5}{|c|}{ Degree of overstory removal } \\
\hline & $\begin{array}{l}\text { Complete, } \\
\text { larger units }\end{array}$ & $\begin{array}{l}\text { Complete, } \\
\text { smaller units }\end{array}$ & Partial & Control & Total \\
\hline & $\ldots \ldots$ & $\ldots \ldots$ & cent (number) & - . . . . & - . . n \\
\hline \multicolumn{6}{|l|}{ Douglas-fir } \\
\hline Died after 1973 & $36.8(7)$ & $18.9(7)$ & $32.6(16)$ & $15.0(15)$ & $21.9(45)$ \\
\hline Live in 1985 & $63.2(12)$ & $81.1(30)$ & $67.4(33)$ & $85.0(85)$ & $78.1(160)$ \\
\hline Total & $100.0(19)$ & $100.0(37)$ & $100.0(49)$ & $100.0(100)$ & $100.0(205)$ \\
\hline \multicolumn{6}{|l|}{ Engelmann spruce } \\
\hline Died after 1973 & $7.7(1)$ & $O(0)$ & $22.9(8)$ & $9.1(4)$ & $13.4(13)$ \\
\hline Live in 1985 & $92.3(12)$ & $100.0(5)$ & $77.1(27)$ & $90.9(40)$ & $86.6(84)$ \\
\hline Total & $100.0(13)$ & $100.0(5)$ & $100.0(35)$ & $100.0(44)$ & $100.0(97)$ \\
\hline \multicolumn{6}{|l|}{ Subalpine fir } \\
\hline Died after 1973 & $10.6(5)$ & $10.6(5)$ & $16.1(5)$ & $14.4(20)$ & $13.3(35)$ \\
\hline Live in 1985 & $89.4(42)$ & $89.4(42)$ & $83.9(26)$ & $85.6(119)$ & $86.7(229)$ \\
\hline Total & $100.0(47)$ & $100.0(47)$ & $100.0(31)$ & $100.0(139)$ & $100.0(264)$ \\
\hline \multicolumn{6}{|l|}{ All species } \\
\hline Died after 1973 & $16.5(13)$ & $13.5(12)$ & $25.2(29)$ & $13.8(39)$ & $16.4(93)$ \\
\hline Live in 1985 & $83.5(66)$ & $86.5(77)$ & $74.8(86)$ & $86.2(244)$ & $83.6(473)$ \\
\hline Total & $100.0(79)$ & $100.0(89)$ & $100.0(128)$ & $100.0(283)$ & $100.0(566)$ \\
\hline
\end{tabular}

Table 7-Regression equations for predicting mean percent defoliation caused by western spruce budworm on Douglas-fir, Engelmann spruce, and subalpine fir

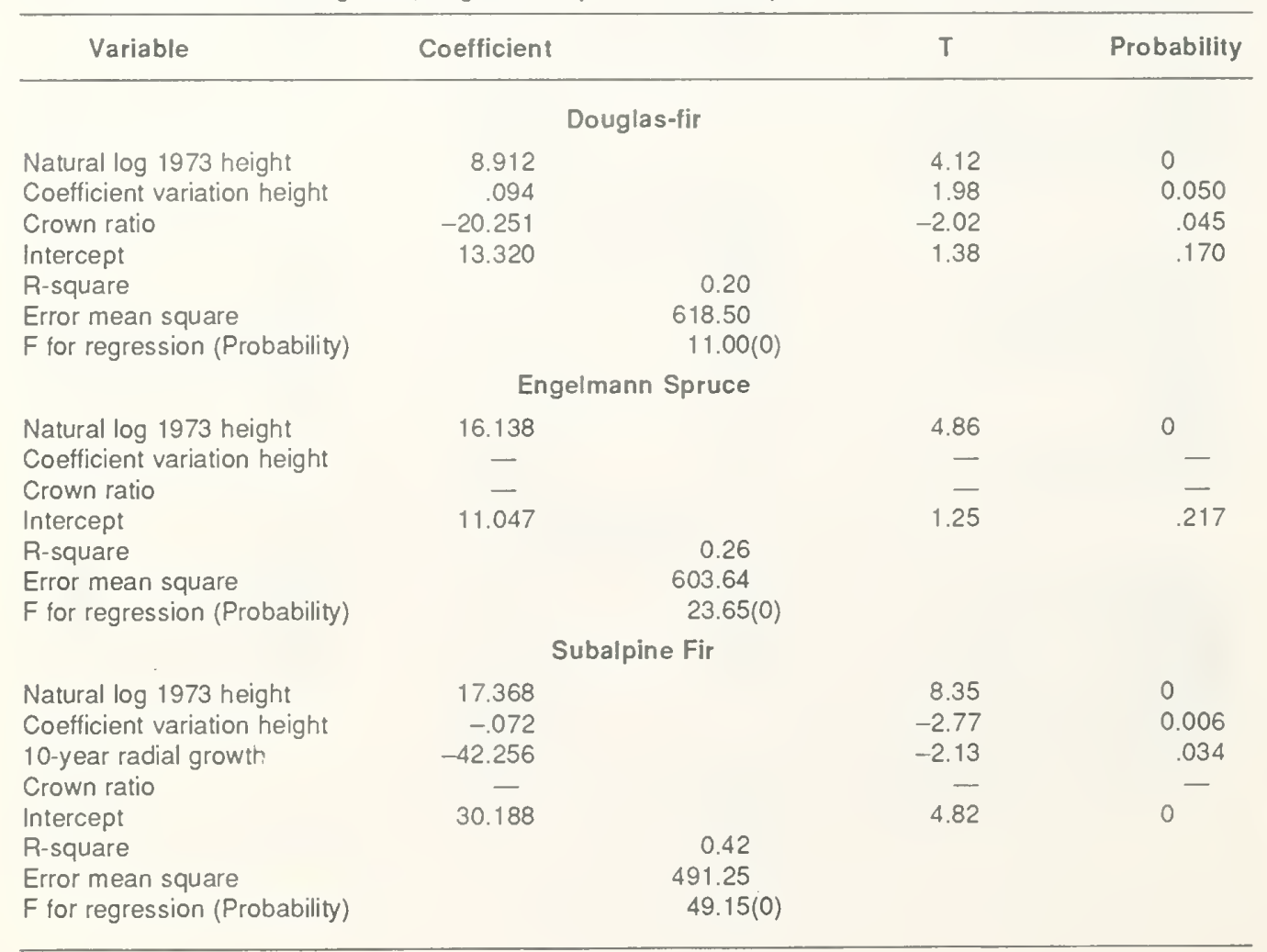




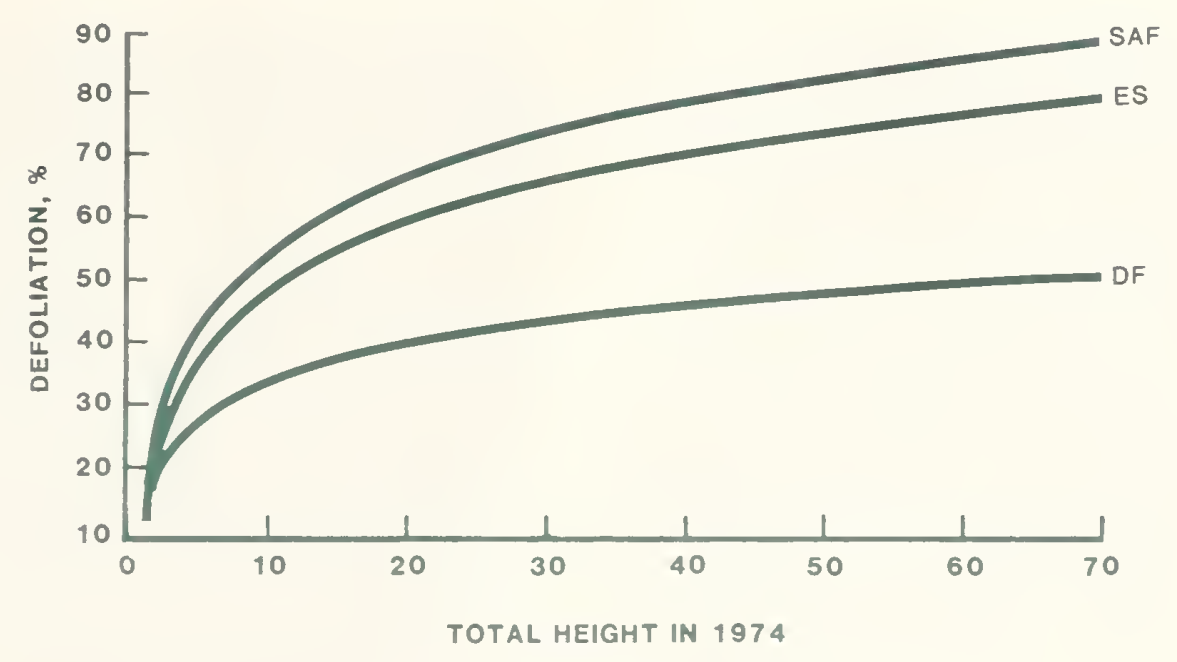

Figure 5-Influence of tree height on western spruce budworm defoliation of Douglas-fir, subalpine fir, and Engelman spruce.

\section{Defoliation}

Defoliation in 1973 by western spruce budworm was significantly related to the natural log and the coefficient of variation (cv) of initial height, most strongly for subalpine fir (table 7). Taller trees sustained more defoliation than smaller ones. Higher cv of Douglas-fir height resulted in slightly increased defoliation, whereas the opposite was true for subalpine fir. The only important independent variable influencing defoliation of Engelmann spruce was natural log of initial height. The coefficient of determination was highest for subalpine fir (0.42) and lowest for Douglas-fir (0.20). Percentage of defoliation is shown as a function of tree height for the three species (fig. 5).

\section{DISCUSSION}

Height and/or diameter growth of all species increased following treatment and were directly related $(P \leq 0.05)$ to at least one of the variables representing competitiondegree of overstory removal or change in plot basal area. Change in plot basal area was calculated as the difference between pretreatment and posttreatment basal area; therefore larger values in basal area change represent decreasing competition. Degree of overstory removal also represents decreasing competition. Some of the overstory basal area was included in the calculation of basal area change when an overstory tree occurred on a plot. Thus, the separation of degree of competition due to plot basal area change or degree of overstory removal was not always clear. So both variables need to be considered as measures of stand competition.

In this respect, the results are sensible. Height growth of Douglas-fir increased with increasing change in plot basal area; height growth of subalpine fir increased with change in basal area and degree of overstory removal (table 3). Engelmann spruce height growth did not respond to either measure of competition, however. McCaughey and Schmidt (1982) showed that subalpine fir tended to release more than spruce, although in their study spruce released only minimally. Diameter growth of all three species increased with decreasing competition. Douglas-fir and Engelmann spruce grew faster as degree of overstory removal increased, whereas subalpine fir responded to increasing change in plot basal area (table 4).

Crown ratio was a significant predictor of postrelease d.b.h. growth of subalpine fir. But the sign of the coefficient was opposite of the expected positive relation; better crown ratios were associated with poorer growth. This anomaly remains unexplained. In spite of the statistical significance, this variable added little to the prediction of height growth. A 50 percent change in crown ratio resulted in only about 1.2 feet of height growth over 11 years.

There was little physical difference between the complete overstory removal on "large" units and complete removal on "small" units. The former were 3 to 5 acres, the latter were about 2 acres and in reality should have been considered identical treatments. This lack of real difference is reflected in the regression models for height and diameter growth. Where degree of overstory removal was statistically important, the coefficients representing both categories of complete removal were similar in size to each other but were quite different from the coefficient representing the partial removal. But because the original study had broader objectives than reported here (Barger 1980), we chose to keep the treatments separate.

Notwithstanding the above discussion on the effect of reduced stand competition on tree growth, the variable exerting the most influence on posttreatment height and diameter growth was radial growth prior to treatment (figs. 1,4). Trees that were vigorous prior to treatment, for whatever reasons, simply outperformed other trees following treatment. This variable was significant in height and diameter models for all three species.

Initial height was not an important predictor in any of our models. Tall trees responded about as well as short ones. Other researchers obtained somewhat different 
results. McCaughey and Schmidt (1982) demonstrated that taller (older) Engelmann spruce and subalpine fir responded slower to release than shorter (younger) trees. Taller suppressed grand fir did not release as well as shorter trees of equal suppression, and younger trees released better than older ones (Ferguson and Adams 1980). Initial diameter in our study was important only in the Douglas-fir model, where larger-diameter trees grew faster than the smaller ones.

Tree age was not used as an independent variable in our study. Unfortunately, much of the age data taken in 1974 was lost and sample size of trees for which ages were available was too small for age to be of use in the analyses. Age was an important variable in several previous studies on release of understory (Ferguson and Adams 1980; McCaughey and Schmidt 1982), and we regret the omission of this variable in our analyses. Plot trees will be remeasured in 1994 when we plan to destructively sample, so age will be determined then and included in subsequent analyses. We did not extract increment cores or disks during the 1985 remeasurement because we did not want to jeopardize future growth of the plot trees.

Trees usually do not respond to reduced competition for 3 or 4 years after treatment. Because we used height and diameter growth as dependent variables over the entire period since cutting, the responses may be conservative. Perhaps we should have used only the most current 5 year height and diameter growth as dependent variables. Such data were not taken during this measurement but will be in 1994. Thus, we expect that the future models will be improvements over the current ones.
Even though most studies on release of advance regeneration report significant increases in height and diameter growth following harvest, the absolute growth is small-usually less than 0.5 foot per year for height and less than 0.2 inch per year for diameter growth during the release period even on productive sites. We looked at results from several different studies done in the Western United States (table 8). (See appendix for notes on how table 8 was derived.) Data selected for inclusion in table 8 represent trees of moderate to good vigor, with crown ratios greater than 50 percent-in other words, the better trees left after harvest. In comparison, good-vigor western larch under even-aged management on average sites will grow about 1 foot in height and 0.28 inch per year in diameter during the first 20 years of growth (Schmidt and others 1976).

Predictive value of most models dealing with postharvest release of residual trees is relatively low, even though the models are statistically significant (table 8 ). Our models are no exception; coefficients of multiple determination for height growth ranged from 0.15 for Engelmann spruce and 0.20 for Douglas-fir to 0.27 for subalpine fir. CD's for diameter growth were higher, ranging from 0.46 for Engelmann spruce and 0.50 for subalpine fir to 0.53 for Douglas-fir in our studies. Similarly, predictive value was not very strong for most of the models developed from other studies on advance regeneration. Coefficients of determination developed by Seidel (1980) ranged from 23.0 to 44.1 for diameter growth and 17.5 to 44.2 for height growth; he did not consider them reliable. Oliver's

Table 8- Height and diameter growth of advance regeneration following harvest, according to several western North American studies

\begin{tabular}{|c|c|c|c|c|c|}
\hline \multirow[b]{2}{*}{ Study/location } & \multirow[b]{2}{*}{ Species } & \multicolumn{2}{|c|}{ Mean annual helght growth } & \multicolumn{2}{|c|}{ Mean annual dlameter growth } \\
\hline & & Preharvest & Postharvest & Preharvest & Postharvest \\
\hline & & \multicolumn{2}{|c|}{$\ldots \ldots$ - Feet- . . . . - } & \multicolumn{2}{|c|}{ - . - . . - Inches - . . . . . } \\
\hline \multirow{3}{*}{$\begin{array}{l}\text { Current } \\
\text { NW Montana }\end{array}$} & Subalpine fir & 0.10 & 0.45 & 0.04 & 0.04 \\
\hline & Engelmann spruce & .16 & .16 & .04 & .15 \\
\hline & Douglas-fir & .12 & .12 & .04 & .09 \\
\hline \multirow{2}{*}{$\begin{array}{l}\text { Johnstone }(1978) / \\
\text { Alberta, Canada }\end{array}$} & Subalpine fir & .20 & .52 & NA & NA \\
\hline & Spruce & .22 & .40 & NA & NA \\
\hline Seidel (1980)/Oregon & Grand fir & .21 & .18 & .05 & .15 \\
\hline $\begin{array}{l}\text { Ferguson and Adams } \\
(1980) / / \text { daho }\end{array}$ & Grand fir & .13 & .42 & NA & NA \\
\hline \multirow{2}{*}{$\begin{array}{l}\text { McCaughey and Schmidt } \\
\text { (1982)/Utah }\end{array}$} & Engelmann spruce & .10 & .50 & NA & NA \\
\hline & Subalpine fir & .17 & .58 & NA & NA \\
\hline $\begin{array}{l}\text { Helms and Standiford } \\
\text { (1985)/California }\end{array}$ & White fir & .46 & .82 & NA & .24 \\
\hline Oliver (1986)/California & Red fir & .46 & .29 & NA & .15 \\
\hline
\end{tabular}


(1986) models also did not adequately explain the variation in growth of red fir. His best equations, developed for the 2-year period just after thinning, explained less than two-thirds of the variation. Equations for 8 years following treatment had CD's of only 0.33 for diameter growth and 0.24 for height growth. Other CD's reported for height growth were: 0.35 (Ferguson and Adams 1980); 0.11 to 0.58 (McCaughey and Schmidt 1982); 0.56 (Helms and Standiford 1985). The highest CD's developed were 0.77 for subalpine fir and 0.72 for spruce height growth in Alberta, Canada (Johnstone 1978). Models for diameter growth generally had higher predictive power than those for height, supporting our findings at Coram. Comparison of CD's across all studies may not be entirely valid because the nature of the dependent variable differed among studies. Nevertheless, the mediocre CD's simply reflect the inherent difficulty in identifying and measuring key factors affecting tree growth in the field. The models reported in the literature are generally state of the art and are likely about the best that can be expected.

Mortality and serious damage caused by logging in our study area were reported earlier (Benson and Gonsior 1981) so we did not include this type of damage in the present study, except that we included mortality caused by logging as part of the basal area change. They reported that more than 40 percent of the trees were either killed or seriously damaged during the harvesting process in the treatments where all the overstory was removed and about 30 percent where only part of the overstory was removed. We documented only mortality that was not obviously caused at the time of harvest. Mortality of advance regeneration less than or equal to 7 inches d.b.h. was least in the complete overstory removal treatments and controls (13 percent) and greatest in the partial removal (25 percent), amounting to about 1 to 2 percent per year, respectively. Among species, a higher proportion of Douglas-fir (22 percent) died than of Engelmann spruce and subalpine fir (13 percent). We do not know why mortality was greater in the partial removals nor why a higher proportion of Douglas-fir died than the other species. Perhaps root diseases were more active, but this presumption is highly speculative. About all we can say is that our mortality rates are, in a general sense, similar to those predicted by Hamilton (1986) for stands in northern Idaho. He predicted 10-year mortality rates of 0.13 in thinned and nonthinned stands on productive sites in northern Idaho, which translates to 1.3 percent per year.

A serious consequence of leaving advance conifer regeneration in the Northern Rocky Mountains is an increase in stand susceptibility to western spruce budworm. Western larch and Douglas-fir when seral tend not to support populations of the insect (Carlson and others 1985). Stands dominated by subalpine fir, Engelmann spruce, and/or grand fir in the overstory or understory are highly susceptible. Two to three years prior to and during establishment of this study in 1973, budworm was active and moderate in the study area; 30 to 50 percent defoliation was present on the advance regeneration. Subalpine fir and Engelmann spruce sustained more defoliation than Douglas-fir. This supports other observations we have made; when Douglas-fir is seral it tends to have less defoliation than its more shade-tolerant associates (Carlson and others 1985). We thought this situation would provide an excellent opportunity to assess differential effects of the insect on advance regeneration. But for unknown reasons, budworm nearly disappeared from the study area after 1975, and we ended up with only 1 year's defoliation data. Even so, we did find a significant effect of defoliation on one species. Increasing defoliation was associated with decreasing height growth of Douglas-fir (fig. 2).

Other studies concerning the influence of defoliation on tree growth support these results. Ferguson (1988) demonstrated that probability of top dieback increased with increasing defoliation, and that periodic height increment was reduced. His study specifically considered defoliation over a 5-year period-longer than our outbreak. Furthermore, at the time he selected his stands, the budworm outbreak was in progress, therefore his sample trees likely were defoliated for more than 5 consecutive years. Proportion of retained foliar biomass was positively related to growth of Douglas-fir and grand fir in central Washington (Nichols 1988), implicating the negative effects of defoliation. In our study we were not able to demonstrate an effect of defoliation on height growth of subalpine fir or Engelmann spruce, even though they sustained more defoliation than Douglas-fir. Perhaps these species, being more shade-tolerant than Douglas-fir, were better able to recover following insect feeding, masking the effect of only 2 years of defoliation.

The amount of defoliation we observed was strongly influenced by tree stature; other variables were of lesser importance. Taller trees of all species incurred more defoliation than smaller trees (table 7). This was expected because budworm tend to feed near the tops of trees but drop down when foliage supplies become limiting. In light to moderate outbreaks such as we experienced in this study, foliage likely was not a limiting factor for the insect so they probably did not move downward very much. Furthermore, budworm larvae on small trees less than 3 feet tall are easy prey for birds and ants-at least half of the larvae on small trees may be removed (Carlson and others 1984). Because defoliation increased with increasing height for all species, potential crop trees-the taller ones with more live crown-may be more at risk than smaller trees. Douglas-fir trees with poor crown ratios, in plots with lots of variation in height, received the most defoliation. Subalpine fir trees with poor prerelease 10-year radial growth, on plots with low variation in height, were impacted most by budworm. The common thread between defoliation on Douglas-fir and subalpine fir appears to be some measure of tree vigor. Poor crown ratios indicate poor vigor for Douglasfir, whereas poor prerelease growth rate seems to be the indicator for subalpine fir.

\section{MANAGEMENT IMPLICATIONS}

This study suggests that culturing advance regeneration on productive sites in the Northern Rocky Mountains may not be wise if the primary objective is to produce timber. Volume production may be mediocre compared to yields expected from seral, even-aged regeneration established following harvest. Furthermore, the increased susceptibility of advance regeneration to western spruce 
budworm should not be taken lightly. Moderate to heavy defoliation in epidemics reduced expected yields more than 18 percent in Douglas-fir stands in British Columbia, Canada (Alfaro and others 1985). Repeated defoliation along with the mediocre height growth response in stands like we studied could result in yield reductions of more than 40 percent at rotation compared to yields from stands composed of seral species. These losses simply would not be acceptable on productive sites where growing timber is deemed important. In contrast, even-aged, seral conifer regeneration established subsequent to harvest will likely incur only light defoliation and little or no impact on height and diameter growth despite high budworm populations in susceptible adjacent stands (Carlson and others 1988).

But if the land manager decides that management of advance regeneration is his best option, after considering all important resource values, here are a few suggestions for enhancing timber values:

1. Select the most vigorous individuals as leave trees. These will be full crowned, deep green in color, with straight boles and rapid terminal leader growth. These trees will release quickest and grow fastest.

2. Remove all of the overstory stand as soon as possible, preferably in one cutting. Try to minimize logging damage to the residual understory because the shadetolerant species are highly vulnerable to stem and root diseases if they are injured.

3. Provide the residual stand with room to grow. A thinning 3 to 4 years following overstory removal may be appropriate. Thinning will reduce susceptibility to western spruce budworm and will encourage rapid growth of residual trees.

4. Give preference to seral tree species. There will always be a few of these in the understory.

\section{REFERENCES}

Alfaro, A. J.; Thomson, A. J.; Van Sickle, G. A. 1985. Quantification of Douglas-fir growth losses caused by western spruce budworm defoliation using stem analysis. Canadian Journal of Forest Research. 15: 5-9.

Arno, Stephen F. 1980. Forest fire history in the Northern Rockies. Journal of Forestry. 78(8): 460-465.

Barger, Roland L. 1980. The forest residues utilization program in brief. In: Environmental consequences of timber harvesting. Gen. Tech. Rep. INT-90. Ogden, UT: U.S. Department of Agriculture, Forest Service, Intermountain Forest and Range Experiment Station: 7-24.

Benson, Robert E.; Gonsior, Michael J. 1981. Tree damage from skyline logging in a western larch/Douglas-fir stand. Res. Pap. INT-268. Ogden, UT: U.S. Department of Agriculture, Forest Service, Intermountain Forest and Range Experiment Station. 15 p.

Carlson, Clinton E.; Campbell, Robert W.; Theroux, Leon J.; Egan, Thomas, H. 1984. Ants and birds reduce western spruce budworm feeding injury to small Douglas-fir and western larch in Montana. Forest Ecology and Management. 9: 185-192.
Carlson, Clinton E.; McCaughey, Ward W.; Theroux, Leon J. 1988. Relations among stand structure, dispersal of second-instar western spruce budworm, defoliation, and height growth of young conifers. Canadian Journal of Forest Research. 18(6): 794-800.

Carlson, Clinton E.; Schmidt, Wyman C.; Fellin, David G.; Wulf, N. William. 1985. Silvicultural approaches to western spruce budworm management in the Northern U.S. Rocky Mountains. In: Sanders, C. J.; Stark, R. W.; Mullins, E. J.; Murphy, J., eds. Recent advances in spruce budworms research. Proceedings-CANUSA Spruce Budworms Symposium; 1984 September 16-20; Bangor, ME. Ottawa, ON: Canadian Forestry Service: 281-297.

Ferguson, Dennis E. 1988. Growth of regeneration defoliated by spruce budworm in Idaho. Res. Pap. INT-393. Ogden, UT: U.S. Department of Agriculture, Forest Service, Intermountain Research Station. 13 p.

Ferguson, Dennis E.; Adams, David L. 1980. Response of advance grand fir regeneration to overstory removal in northern Idaho. Forest Science. 26(4): 537-545.

Grizzle, James E.; Starmer, C. Frank; Koch, Gary G. 1969. Analysis of categorical data by linear models. Biometrics. 25: 489-504.

Hamilton, David A. 1986. A logistic model of mortality in thinned and unthinned mixed conifer stands of northern Idaho. Forest Science. 32: 989-1000.

Helms, John A.; Standiford, Richard B. 1985. Predicting release of advance reproduction of mixed conifer species in California following overstory removal. Forest Science. 31(1): 3-15.

Johnson, Phillip C.; Denton, Robert E. 1975. Outbreaks of the western spruce budworm in the American Northern Rocky Mountain area from 1922 through 1971. Gen. Tech. Rep. INT-20. Ogden, UT: U.S. Department of Agriculture, Forest Service, Intermountain Forest and Range Experiment Station. $144 \mathrm{p}$.

Johnstone, W. D. 1978. Growth of fir and spruce advance growth and logging residuals following logging in westcentral Alberta. Inf. Rep. NOR-X-203. Edmonton, AL: Canadian Forestry Service, Northern Forestry Research Centre. 16 p.

Marsden, Michael A. 1983. Modeling the effect of wildfire frequency on forest structure and succession in the Northern Rocky Mountains. Journal of Environmental Management. 16: 45-62.

McCaughey, Ward W.; Schmidt, Wyman C. 1982. Understory tree release following harvest cutting in spruce-fir forests of the Intermountain West. Res. Pap. INT-285. Ogden, UT: U.S. Department of Agriculture, Forest Service, Intermountain Forest and Range Experiment Station. 19 p.

Nichols, Thomas J. 1988. The relationship between western spruce budworm defoliation levels and growth of individual Douglas-fir and grand fir trees. Forest Science. 34(2): 496-504.

Oliver, William W. 1986. Growth of California red fir advance regeneration after overstory removal and thinning. Res. Pap. PSW-180. Berkeley, CA: U.S. Department of Agriculture, Forest Service, Pacific Southwest Forest and Range Experiment Station. 6 p. 
Pfister, Robert D.; Kovalchik, Bernard L.; Arno, Stephen F.; Presby, Richard C. 1977. Forest habitat types of Montana. Gen. Tech. Rep. INT-34. Ogden, UT: U.S. Department of Agriculture, Forest Service, Intermountain Forest and Range Experiment Station. 174 p.

SAS Institute. 1985. SAS user's guide: statistics. Version 5 ed. Cary, NC: SAS Institute. 956 p.

Schmidt, Wyman C.; Shearer, Raymond C.; Naumann, John R. 1983. Western larch. In: Silvicul tural systems for the major forest types of the United States. Agric. Handb. 445. Washington, DC: U.S. Department of Agriculture, Forest Service: 56-58.
Schmidt, Wyman C.; Shearer, Raymond C.; Roe, Arthur L. 1976. Ecology and silviculture of western larch forests. Tech. Bull. 1520. Washington, DC: U.S. Department of Agriculture, Forest Service. 96 p.

Seidel, K. W. 1980. Diameter and height growth of suppressed grand fir saplings after overstory removal. Res. Pap. PNW-275. Portland, OR: U.S. Department of Agriculture, Forest Service, Pacific Northwest Forest and Range Experiment Station. 9 p. 


\section{APPENDIX: DERIVATION OF VALUES IN TABLE 8}

CURRENT STUDY. Used regression models and for 11-year height and 12-year d.b.h. models. Pretreatment height growth, although not measured, was assumed to be similar to the posttreatment growth of the control stands.

JOHNSTONE (1978). Estimated height growth from curves in fig. 1 and fig. 2. Used curve for $4.0 \mathrm{ft}$ average height, and 10 years after logging. Estimates are $8 \mathrm{ft}$ at 10 years after logging and $4 \mathrm{ft}$ at logging, so net is $4 \mathrm{ft}$, or $0.4 \mathrm{ft}$ per year after harvest. We extrapolated curves 10 years prior to harvest and used the same technique. (Weak, but probably reasonably accurate). Johnstone had no diameter growth information for the advance regeneration.

SEIDEL (1980). Direct from table 1, line 1 (for all trees), for height and diameter. Preharvest diameter growth was assumed to be the same as the growth for 1975-76, the period just following harvest, because he did not cut down trees so he could measure preharvest growth.

FERGUSON AND ADAMS (1980). Height estimated from fig. 2, changing centimeters to feet.
McCAUGHEY AND SCHMWT (1982). Height estimated from fig. 13. All four forests were similar, so we chose the Dixie, which may have a little slower growth than the others, but not significantly so.

HELMS AND STANDIFORD (1985). Used data from table 2, for the $20-30-\mathrm{cm}$ release class. Assumed $25 \mathrm{~cm}$ as average postrelease growth, and converted to feet. Prerelease data taken directly from table. Postrelease diameter growth was obtained from page 9,item 2 . We used growth for the intermediate prerelease diameter, and converted to feet. Except for reference to Standiford's MS thesis, this paper contains no information on prerelease diameter growth rate.

OLIVER (1986). Used figures in table 2. Used mean value of $Y$ for the 0-8 year period, and divided by 8 to get annual diameter growth after harvest and thinning. No data for preharvest diameter growth. For preharvest height growth, we used table 1 , and live crown pct of 70 , where 3 -year growth $=1.39$. This value was converted to annual growth. For postharvest height growth, we used table $2,0-8$ year period, and divided by 8 to get annual mean growth of $0.29 \mathrm{ft}$. According to Oliver's data, for a given type of tree, height growth rate decreased following harvest and thinning.

Carlson, Clinton E.; Schmidt, Wyman C. 1989. Influence of overstory removal and western spruce budworm defoliation on growth of advance conifer regeneration in Montana. Res. Pap. INT-409. Ogden, UT: U.S. Department of Agriculture, Forest Service, Intermountain Research Station. $14 \mathrm{p}$.

Twelve-year postharvest diameter growth of advance Douglas-fir, Engelmann spruce, and subalpine fir regeneration and 11-year height growth of Douglas-fir and subalpine fir accelerated in response to decreasing competition. Competition was reflected in degree of overstory removal and change in plot basal area. Notwithstanding the influence of change in competition, the most influential variable affecting postharvest height and diameter growth was 10-year radial growth prior to overstory removal; trees growing well before harvest grew well after harvest. Postharvest mortality was greatest where about 50 percent of the overstory was removed. Defoliation by western spruce budworm reduced growth of Douglas-fir but did not affect subalpine fir or Engelmann spruce.

KEYWORDS: competition, stand density, insect impact, release 